\title{
Correlation between Parasitic Infections in HIV Patients Parasitic Infections in HIV Patients
}

\author{
Machado ER*1-4, Santos $\mathrm{LMR}^{2}$, Almeira RLG ${ }^{2}$, Sales IMP², Sousa $\mathrm{SA}^{3}$, Eduardo AMLN ${ }^{3}$, Chaves PLG ${ }^{2,3}$, \\ Oliviera $\mathrm{LB}^{2,3}$ and Affonso $\mathrm{RS}^{3}$ \\ ${ }^{1}$ Department of Biology, Brazil \\ ${ }^{2}$ Department of Biology Biomedicine, Brazil
}

${ }^{3}$ Department of Biology Pharmacy, Brazil

${ }^{4}$ Faculty of Medicine, Brazil

*Corresponding author: Eleuza Rodrigues Machado, Department of Biology, Biomedicine, Pharmacy and Nursing Courses, QS01, Rua 212, Lotes 11/12, S/N, Taguatinga, DF, CEP 71950550, Brazil

\section{ARTICLE INFO}

Received: 慧 February 01, 2019

Published: 慧 February 21, 2019

Citation: Machado ER, Santos LMR, Almeira RLG, Sales IMP, Sousa SA, Eduardo AMLN, Chaves PLG, Oliviera LB, Affonso RS. Correlation between Parasitic Infections in HIV Patients Parasitic Infections in HIV Patients. Biomed J Sci \& Tech Res 15(1)-2019. BJSTR. MS.ID.002631.

\section{ABSTRACT}

Individuals with Human Immunodeficiency Virus (HIV) have a predisposition to opportunistic infections. This study aimed to determine the prevalence of parasitic infections in patients with HIV/AIDS, attended at the Joint Health Unit of Taguatinga in the Federal District, Brazil. Field research of cross-sectional, quantitative and exploratory character was conducted. Data were collected from patient records available in the Archival System of the Health Unit from 2005 to 2015 . We analyzed 502 medical records of patients with HIV/AIDS: 307 men and 195 women. 158 men and 71 women were homosexual, 68 men and 01 woman were bisexual, and 21 men and 9 women had not sexual preferences. 419 patients did not have parasitological or serological tests performed after HIV infection. Among those who had been tested the parasites detected were: Ascaris lumbricoides, Entamoeba histolytica, Giardia lamblia, Strongyloides stercoralis, Trypanosoma cruzi and Toxoplasma gondii. The commensal Entamoeba coli were also found. The reduced helminths number and pathogenic protozoa found is due to small number of tests performed. So, it is necessary to increase requests for parasitological examinations in this population to prevent comorbidity enteroparasites and HIV infections, improving the quality of life of these patients.

Keywords: HIV; AIDS; Parasitic infections; Opportunistic infections; Distrito Federal

\section{Introduction}

Human Immunodeficiency Virus (HIV) is a retrovirus of the Retroviridae family and the etiologic agent of Acquired Immunodeficiency Syndrome (AIDS). When first described in the United States, in 1970, this virus was observed mainly in male homosexuals, hemophiliacs and intravenous drug users [1,2]. Currently, other groups are infected with HIV, including the elderly and wives of men who have sex lives outside of marriage [3]. The genetic material of the HIV is RNA, double-stranded and enveloped. It has the ability to attach and invade mainly CD4+ lymphocytes because of CD4 receptor presence [4]. Other cells also may be invaded by HIV due to its ability to recognize other types of cellular receptors such as the CCR5 receptor present in dendritic cells, macrophages and T cells [5,6]. HIV transmission occurs through unprotected heterosexual and homosexual intercourse. Vertical transmission occurs when the virus breaks through the placental barrier during birth, or by breastfeeding [6].

Another method of transmission is the sharing of needles by drug users, the use of some cutting or perforating utensils containing HIV infected blood [7]. Patients with HIV/AIDS experience an asymptomatic phase followed by the appearance of symptoms. The symptomatic phase is characterized by severe expressions of immunodeficiency and general clinical complications. Significantly, at this point, the patient may develop some opportunistic infection [8]. Parasitic infections are responsible for significant morbidity 
as well as mortality worldwide [9]. In developing countries, they are considered a serious public health problem due to inadequate sanitation and lack of information, which makes the perpetuation of the life cycle of the parasites possible [10]. In these patients, parasitic infections, which are usually asymptomatic, become symptomatic and progress to serious disease, and causing death [11]. Helminths and protozoan, which affect humans and cause many symptoms, are usually associated with the gastrointestinal tract. These diseases are related to demographic, socioeconomic, physiological and immunological factors.

Thus, immunocompromised patients and/or those undergoing immunosuppressive therapy are more susceptible to contracting infections by these parasites and often with a higher degree of severity. Among the frequent intestinal parasites and related diarrhea in patients with HIV are: Entamoeba histolytica, Giardia lamblia, Ancylostomatidae, Ascaris lumbricoides, Strongyloides stercoralis and others [12,13]. People infected with HIV, enteric infections occur more frequently. Some cases are more likely to have severe recurrence and persistence. In most cases the microorganisms are not identified, although there are potential causes of diarrhea whose sources can be some form of parasitic infection [14]. Overall, these facts motivated the present research which aimed to determine the prevalence of parasitic infections in infected HIV/AIDS patients using medical records of patients who had been or were being assisted by the Joint Health Unit in Taguatinga, DF, during the period from 2005 to 2015.

\section{Methodology}

A program of transversal, quantitative and exploratory field research was carried out. The information was collected from medical records of patients with HIV/AIDS. Data were obtained from the Archival System of the Joint Health Unit of Taguatinga, DF. The data included follow-up patients and those who had been referred to be treated and monitored in other hospitals of the regional cities of Brasília, DF. The Ethics Committee of the Foundation of Teaching and Research in Health Sciences (FEPECS) approved the project (Process: 05163312.3.0000.5553 of 04/02/2013).

\section{Target Population}

Patients included those who had been diagnosed with HIV/ AIDS and who were or had been monitored and/or who were or had been in treatment at the Joint Health Unit, Taguatinga, DF, from January 2005 to July 2015. The survey was conducted at the Joint Health Unit in Taguatinga, DF, Brazil, and analyzed 502 medical records of these patients.

\section{Criteria for Inclusion and Exclusion of Patients in the Sample}

The records examined contained information regarding socioeconomic factors, gender, age, origin, profession, sexual preference, diagnostic tests performed, and medications administered, among other data. Records of patients who had not been diagnosed with HIV/AIDS, who were outside the established period or contained insufficient data to complete the questions, were excluded.

\section{Variable Selection}

Data were collected from patient charts, available in Archival System of the Joint Health Unit Taguatinga, DF. The variables chosen for the study were selected from the data included in the charts.

\section{Biosecurity Standards}

The study involved no invasive methods. For this reason, the Biosecurity Standards did not apply. The research was, however, in compliance with the recommendations of Resolution No. 196/96 of the National Health Council, maintaining the anonymity of the information that could identify patients with HIV/AIDS.

\section{Sharing of Results}

The survey results were passed on to the local group of professionals in this research area. It is very important to identify and differentiate the microorganisms that cause opportunistic infections in immunocompromised patients. For these patients the manifestation of diseases is usually more severe. Furthermore, to bring the situation under control, information and awareness are necessary. The health professionals, who deal with these issues, have the opportunity to inform patients about the necessary precautions to avoid contamination with opportunistic pathogens such as bacteria, fungi, protozoa, helminths and other pathogens.

\section{Statistical Analysis}

Data were organized in tables and graphs. The statistical analyses were conducted using Chi Square $\left(\mathrm{X}^{2}\right)$ with the INSTAT 3 statistical program. Correlations were considered statistically significant at $\mathrm{p}<.0 .5$

\section{Results}

The distribution of the HIV-positive patients of the sample, by age group, gender and sexual orientation, is shown in Table 1. Most patients had been subjected to more than one test to confirm HIV. During the period from 1999 to 2004, three patients had undergone Elisa, 10 had been tested using Western blotting, two had been diagnosed using indirect immunofluorescence, three had had rapid tests and six had been examined by antibody Screening Anti-HIV 1 and 2. The distribution of HIV-positive patients, compared by the year of diagnosis and confirmatory tests performed, as well as the $\mathrm{CD} 4{ }^{+}$cell counts, are presented in Table 2 . Correlations between the diagnosis of HIV infection based on symptoms such as eosinophilia and parasitological test results of the patients of the sample, as well as the common symptoms reported that could be indicative of infection by parasites, helminths and protozoa, are shown in Table 3. 
Table 1: Distribution of HIV-positive patients by age group, gender and sexual orientation, treated at the Joint Health Unit Taguatinga,

Federal District, during the period 2005-2015.

\begin{tabular}{|c|c|c|c|c|c|c|c|c|c|c|c|c|c|c|c|c|c|c|}
\hline \multicolumn{19}{|c|}{ Gender } \\
\hline \multirow[t]{2}{*}{ Age } & \multicolumn{9}{|c|}{ Male } & \multicolumn{9}{|c|}{ Female } \\
\hline & Total & Ht & $\%$ & $\mathrm{Hm}$ & $\%$ & $\mathbf{B i}$ & $\%$ & NR & $\%$ & Total & $\mathrm{Ht}$ & $\%$ & $\mathrm{Hm}$ & $\%$ & $\mathrm{Bi}$ & $\%$ & NR & $\%$ \\
\hline $15-\mid 35$ & 129 & 27 & 8.8 & 77 & 25.1 & 20 & 6.5 & 5 & 1.6 & 65 & 37 & 19.0 & 23 & 11.8 & 1 & 0.5 & 4 & 2.1 \\
\hline 35-55 & 119 & 33 & 10.7 & 53 & 17.3 & 29 & 9.4 & 4 & 1.3 & 72 & 42 & 21.5 & 28 & 14.4 & 0.0 & 0.0 & 2 & 1.0 \\
\hline $55-\mid 75$ & 59 & 10 & 3.3 & 28 & 9.1 & 18 & 5.9 & 3 & 1.0 & 58 & 35 & 17.9 & 20 & 10.3 & 0.0 & 0.0 & 3 & 1.5 \\
\hline Total & $307^{*}$ & & & & & & & & & 195 & & & & & & & & \\
\hline
\end{tabular}

Note: M: Male; F: Female; Ht: Heterosexual; Hm: Homosexual; Bi: Bisexual; NR: not reported; \%: Percentage; * Significative difference.

Table 2: Distribution of HIV-positive patients at the Joint Health Unit Taguatinga-DF, by year of diagnosis, confirmatory tests and CD4+ cell count, Federal District, during the period 2005-2015.

\begin{tabular}{|c|c|c|c|c|c|c|c|c|c|c|c|c|c|c|c|c|}
\hline \multirow[t]{2}{*}{ Test (Year) } & \multicolumn{10}{|c|}{ HIV confirmatory test } & \multicolumn{6}{|c|}{ CD4+ $T$ cell count } \\
\hline & El & $\%$ & Wb & $\%$ & II & $\%$ & Rt & $\%$ & Sa & $\%$ & $>500$ & $\%$ & $>200$ & $\%$ & $<200$ & $\%$ \\
\hline $1999 \dashv 2004$ & 3 & 0.6 & 10 & 2.0 & 2 & 0.4 & 3 & 0.6 & 6 & 1.2 & 37 & 7.4 & 29 & 5,8 & 41 & 8.2 \\
\hline $2004 \dashv 2009$ & 8 & 1.6 & 23 & 4.6 & 16 & 3.2 & 8 & 1.6 & 10 & 2.0 & 48 & 9.6 & 51 & 10.1 & 59 & 11.7 \\
\hline $2009-2015$ & 23 & 4.6 & 72 & 14.3 & 37 & 7.3 & 49 & 9.8 & 51 & 10.6 & 73 & 14.5 & 61 & 12.2 & 103 & 20.5 \\
\hline
\end{tabular}

Note: El: Elisa; Wb: Western blotting; II: Indirect Imunofluorescence; Rt: Rapid test; Sa: Screening antibodies Anti-HIV 1 and 2.

Table 3: Correlations between the diagnosis of infection with HIV, time period of clinical symptoms and parasitological examination results of patients at the Joint Health Unit Taguatinga, Federal District, during the period 2005-2015.

\begin{tabular}{|c|c|c|c|c|c|c|c|c|c|c|c|}
\hline \multicolumn{1}{|c|}{ HIV Carrier time } & \multicolumn{9}{|c|}{ Symptoms } & \multicolumn{4}{c|}{ Parasitological tests performed } \\
\hline No. of cases & Time (Year) & Dh. & \% & Wl. & \% & Eo. & \% & Yes & \% & N & \% \\
\hline 192 & 1 & 52 & 10.4 & 68 & 13,5 & 66 & 13,1 & 32 & 6,4 & 160 & 31.9 \\
\hline 57 & 2 & 23 & 4.6 & 24 & 4.8 & 17 & 3.4 & 15 & 2.9 & 422 & 8.4 \\
\hline 31 & 3 & 12 & 2.4 & 29 & 5.8 & 10 & 2.0 & 8 & 1.6 & 23 & 4.6 \\
\hline 22 & 4 & 9 & 1.8 & 15 & 3.0 & 8 & 1.6 & 5 & 0.9 & 17 & 3.4 \\
\hline 24 & 5 & 10 & 2.0 & 14 & 2.8 & 6 & 1.2 & 3 & 0.6 & 21 & 4.2 \\
\hline 26 & 6 & 8 & 1.6 & 18 & 3.6 & 10 & 2.0 & 6 & 1.2 & 20 & 3.9 \\
\hline 18 & 7 & 4 & 0.8 & 6 & 1.2 & 3 & 0.6 & 7 & 1.4 & 11 & 2.2 \\
\hline 24 & 8 & 1 & 0.2 & 10 & 2.0 & 2 & 0.4 & 1 & 0.2 & 23 & 4.6 \\
\hline 32 & 9 & 2 & 0.4 & 5 & 1.0 & 1 & 0.2 & 3 & 0.6 & 29 & 5.8 \\
\hline 22 & 10 & 3 & 0.6 & 6 & 1.2 & 5 & 1.0 & 0 & 0.0 & 22 & 4.4 \\
\hline 54 & $>10$ & 25 & 5.0 & 35 & 7.0 & 12 & 4.2 & 3 & 0.6 & 51 & 10.1 \\
\hline
\end{tabular}

Note: No: Number; \%: Percentage; Dh: Diarrhea; Wl; Weight loss; Eo: Eosiniphilia.

A total of 149 patients were diagnosed with diarrhea, 230 had weight loss and 140 were eosinophilia. Of the patients with diarrhea, 37 tested positive for intestinal parasites or commensals: 19 for Entamoeba coli, nine for E. histolytica, three for S. stercoralis, one for G. lamblia and five for A. lumbricoides. Of the patients who had weight loss, 11 were positive for intestinal parasites or commensals: five for $E$. coli, two for E. histolytica, one for $S$. stercoralis, and three for $A$. lumbricoides. In addition, of those with eosinophilia: 34 were positive for enteroparasites or commensals:
18 for E. coli, eight for E. histolytica, two for S. stercoralis, one for G. lamblia and five for A. lumbricoides. The frequency of parasites and/or commensals diagnosed in HIV-positive patients using parasitological and immunological methods is shown in Table 4. Of the total of 502 patients, 83 had undergone parasitological tests and of these 42 were positive. The most common commensal was E. coli with 22 cases. Of 483 patients who underwent immunological tests, 193 cases were positive for toxoplasmosis, and 11were positive for Chagas disease. 
Table 4: Parasitological and immunological test results and species of parasites and commensals found in HIV-positive patients, the Joint Health Unit Taguatinga, Federal District, during the period 2005-2015.

\begin{tabular}{|c|c|c|c|c|c|c|c|c|c|c|c|c|c|}
\hline \multirow{2}{*}{ Tests } & \multicolumn{6}{|c|}{ Results } & \multicolumn{5}{|c|}{ Parasitological Parasites and commensals } & \multicolumn{2}{|c|}{ Immunological Protozoa } \\
\hline & $\mathbf{N}$ & $\%$ & $\mathbf{P}$ & $\%$ & NR & $\%$ & $E c$. & Eh. & Ss. & GI. & Al. & Tg. & $T c$. \\
\hline Parasitological & 41 & 8,2 & 42 & 8,4 & 419 & 83,5 & 22 & 12 & 5 & 3 & 6 & - & - \\
\hline Immunological & 279 & 55,6 & 204 & 40,6 & $19 *$ & 3,8 & - & - & - & - & - & 193 & 11 \\
\hline
\end{tabular}

Note: N: Negative; P: Positive: NR: Not performed*; \%: Percentage: Ec: Entamoeba coli; Eh: Entamoeba histolytica; Ss: Strongyloides stercoralis; Gl: Giardia lamblia; Al: Ascaris lumbricoides; Tg: Toxoplasma gondii; Tc: Trypanosoma cruzi

\section{Discussion}

The age group most affected by HIV a few years ago was 20 to 40 years and men were more prevalent than women [15]. The results found in the present study corroborate these findings. The most affected patients were men (61.2\%), then women (38.8\%). The most infected age group was between 15-35 years of age for males. Women were most affected between 35-55 years of age. These data show that women are contracting the virus at a younger age and the number of infected women has grown over the years $[16,17]$. HIV/AIDS primarily affects homosexuals and drug users $[1,18]$. In asymptomatic homosexuals, an increase of cytotoxic $\mathrm{T}$ lymphocytes and suppressor $\mathrm{T}$ lymphocytes was observed. In terms of sexual behavior, more men aged 15-35 years were affected by HIV. Of these, $8.8 \%$ were heterosexual, $25.1 \%$ homosexual, $6.5 \%$ bisexual and $1.6 \%$ did not report sexual preference. Among women, the most prevalent age group affected by HIV was between 35-55 years, with $21.5 \%$ heterosexual, $14.4 \%$ homosexual, no cases of bisexuals and $2 \%$ did not report sexual preference. The findings confirm results reported in the literature: the male age group with the highest rates of HIV is the homosexuals and among women it is the heterosexuals [19].

The first reported cases of HIV described clinical changes related to the gastrointestinal tract. Most cases noted diarrheal conditions associated with parasitosis [19]. In a study conducted at the University Hospital of Rio de Janeiro, the parasite most often observed was A. lumbricoides [20]. In another study conducted in Rio Grande do Sul, the most common intestinal parasites were $T$. trichiura, G. lamblia and A. lumbricoides [21]. In the present study, intestinal parasites and commensals diagnosed in parasitological stool tests were: E. coli (most frequent, with 22 cases), E. histolytica, S. stercoralis, G. lamblia and A. lumbricoides. E. histolytica causes amoebiasis. Protozoan infections usually occur in regions where sanitary conditions are poor and typically spread by fecal-oral contamination [22]. In patients with HIV/AIDS, E. histolytica deserves special attention because it can cause fulminant amoebic dysentery $[23,24]$.

G. lamblia is common both worldwide and in the Brazilian population [24]. It infects individuals of all ages, genders, races and social conditions [12]. The frequency of giardiasis in the present study (three cases) was low compared to other research $[20,25]$.
This may be related to the age factor, since all individuals examined were adults and possibly the personal hygiene conditions were adequate, or because the water used by the population had been treated or filtered. It may also be related to the small number of samples analyzed. E. coli is a commensal, usually acquired by ingestion of contaminated food [26], as reported in patients with HIV [16]. The amount of $E$. coli found (22 cases) in the present study was relatively low, but it corroborate with the literature that show the frequency this commensals in patients HIV positive [27]. A. lumbricoides is the most common intestinal parasite in the world [28]. This disease can affect physical and mental well-being, hinder learning in children and adolescents and is even more complicated for patients with serious diseases such as HIV/AIDS [29]. The frequency of $A$. lumbricoides (six cases) in the present study was similar to the studies reported in the literature [21,27].

Strongyloidiasis is a parasitic disease caused by S. stercoralis and occurs in tropical and subtropical countries [12,30]. One possible means of transmission is by homosexual relationships. The biological cycle is made possible by internal and external autoinfection, by which large amounts of infective larvae are produced and can complete the autoinfection cycle and spread in the body, causing death in patients with HIV/AIDS [31]. Thus, strongyloidiasis can be considered an opportunistic infection with an AIDS-related agent [32]. The depression of cellular immunity is the conditioning factor for spread of strongyloidiasis [33,34]. Results of the present study were similar to previous studies, with low prevalence of $S$. stercoralis (five cases) [20,21]. Among the patients who had had immunological tests, 193 cases tested positive for reagents of T. gondii (toxoplasmosis). T. gondii is the causative agent of toxoplasmosis, it has a complex life cycle with two hosts, and several modes of transmission including blood transfusions, and transplants [35]. In Brazil, toxoplasmosis infection among those with the human immunodeficiency virus is of great importance since it is the major infectious disease found in pregnant women [36]. Toxoplasmosis is, therefore, of great medical importance as a frequent cause of death, especially in infants $[37,38]$.

In the present study, T. gondii was the most frequent protozoan (193 cases) diagnosed by the immunological tests. Eleven patients of the study were seropositive for T. cruzi infection, or Chagas' disease. The correlation of the disease with HIV is worrisome 
because the literature has shown that the reactivation of Chagas disease in immunosuppressed patients is high and associated with many cases of death [39]. Infection with T. cruzi occurs mainly through diet and blood transfusion [40]. Opportunistic infections are frequent characteristics of HIV patients and often occur due to the depletion of $\mathrm{CD} 4^{+} \mathrm{T}$ cells in number and function. But these infections can also infect and alter macrophages, Langerhans cells, dendritic cells, and $\mathrm{CD}^{+}$lymphocytes. It is for this reason that HIV patients are more susceptible to secondary infections [16]. In a study conducted in São Paulo, 53.6\% of patients with HIV had CD $4^{+}$ cell counts of less than $200 / \mathrm{mm}^{3}$ [27]. In the present study, the CD $4^{+}$ cell counts of less than $200 / \mathrm{mm}$ were found among $8.2 \%$ of the patients studied from 1999 to 2004; from 2004 to 2009 it increased to $11.7 \%$ and from 2009 to 2015 it was $20.5 \%$.

\section{Conclusion}

In conclusion, it is very important to monitor the evolution of AIDS in patients in Brasília since parasitic infections caused by helminths, protozoa are frequent, and many deaths can be avoided if these pathogens are correctly diagnosed and treated. However, for such treatments to be administered in time it is necessary that serological and parasitological examinations become routine for these patients. This procedure is totally dependent on the request for the examinations by the health care professionals who provide care to these individuals.

\section{Acknowledgement}

Appreciation is expressed to the employees of the Taguatinga Joint Health Unit, Federal District, for their support and assistance in the collection of data in the records.

\section{References}

1. Mmbaga EJ, Moen K, Makyao N, Mpembeni R, Leshabari MT (2017) HIV and STI s among men who have sex with men in Dodoma municipality, Tanzania: a cross-sectional study. Sex Transm Infect. Sex Transm Infect. 93(5): 314-319.

2. Kucharska M, Inglot M, Szymczak A, Rymer W, Zalewska M, et al. (2016) Co-Infection of the Hepatitis C Virus With Other Blood-Borne and Hepatotropic Viruses Among Hemophilia Patients in Poland. Hepat Mon 16(9): e35658.

3. Mothe B, Perez I, Domingo P, Podzamczer D, Ribera E, et al. (2009) HIV-1 infection in subjects older than 70: a multicenter cross-sectional assessment in Catalonia, Spain. Curr HIV Res 7(6): 597-600.

4. Li N, Guo F, Li G, Han Y, Xie J, et al. (2015) The clinical characteristics of twenty-five cases of acute HIV-1 infection in China. Zhonghua Nei Ke Za Zhi 54(10): 846-850.

5. Di Napoli SR, Ortiz AM, Wu F, Matsuda K, Twigg HL 3rd, et al. (2017) Tissue-resident macrophages can contain replication-competent virus in antiretroviral-naive, SIV-infected Asian macaques. JCI Insight 2(4): e91214.

6. Hale M, Mesojednik T, Romano Ibarra GS, Sahni J, Bernard A, et al. (2017) Engineering HIV-Resistant, Anti-HIV Chimeric Antigen Receptor T Cells. Mol Ther 25(3): 570-579.

7. Sewell J, Miltz A, Lampe FC, Cambiano V, Speakman A, et al. (2017) Attitudes to and Understanding of Risk of Acquisition of HIV (AURAH) Study Group. Poly drug use, chemsex drug use, and associations with sexual risk behaviour in HIV-negative men who have sex with men attending sexual health clinics. Int J Drug Policy 43: 33-43.
8. Rogerson SJ, Unger HW (2016) Prevention and control of malaria in pregnancy - new threats, new opportunities? Expert Rev Anti Infect Ther 15(4): 1-15.

9. Greene G, Sriruttan C, Le T, Chiller T, Govender NP (2017) Looking for fungi in all the right places: screening for cryptococcal disease and other AIDS-related mycoses among patients with advanced HIV disease. Curr Opin HIV AIDS. 12(2): 139-147.

10. Kashyap B, Sinha S, Das S, Rustagi N, Jhamb R (2010) Efficiency of diagnostic methods for correlation between prevalence of enteric protozoan parasites and HIV/AIDS status--an experience of a tertiary care hospital in East Delhi. J Parasit Dis 34(2): 63-67.

11. Del Pilar Morales EA, Cardona Rodríguez Z, Bertrán Pasarell J, Soto Malave R, De León-Borras R (2016) Multiple Simultaneous Gastrointestinal Parasitic Infections in a Patient with Human Immunodeficiency Virus. P R Health Sci J 35(2): 97-99.

12. Matey EJ, Tokoro M, Mizuno T, Matsumura T, Nagamoto T, et al. (2016) Positive correlation of HIV infection with Giardia intestinalis assemblage B but not with assemblage A in asymptomatic Kenyan children. AIDS 30(15): 2385-2387

13. Jegede EF, Oyeyi ET, Bichi AH, Mbah HA, Torpey K (2014) Prevalence of intestinal parasites among HIV/AIDS patients attending Infectious Disease Hospital Kano, Nigeria. Pan Afr Med J 17: 295.

14. Shah S, Kongre V, Kumar V, Bharadwaj R (2016) A Study of Parasitic and Bacterial Pathogens Associated with Diarrhea in HIV-Positive Patients. Cureus 8(9): e807.

15. Shen ZW, Dai SY, Ye DQ (2017) Intention to undergo HIV testing and associated factors among women in 1 high-HIV prevalence city. Int J Nurs Pract 23(3): e12533.

16. Kuete M, Yuan $\mathrm{H}$, Tchoua Kemayou AL, Songo EA, Yang F, et al. (2016) Escale up use of family planning services to prevent maternal transmission of HIV among discordant couples: a cross-sectional study within a resource-limited setting. Patient Prefer Adherence 10: 19671977.

17. Elmes J, Skovdal M, Nhongo K, Ward H, Campbell C, et al. (2017) Reconfiguration of the sex trade: How social and structural changes in eastern Zimbabwe left women involved in sex work and transactional sex more vulnerable. PLoS One 12(2): e0171916.

18. Mmbaga EJ, Moen K, Makyao N, Mpembeni R, Leshabari MT (2017) HIV and STI s among men who have sex with men in Dodoma municipality, Tanzania: a cross-sectional study. Sex Transm Infect 93(5): 314-319.

19. Xu Y, Peng X, Xie T, Lu X, Wu N. (2017) Identification of a Novel HIV Type 1 Recombinant Form (CRF01_AE/CRF07_BC) in Men Who Have Sex with Men in Zhejiang, China. AIDS Res Hum Retroviruses 33(7): 728-734.

20. Rivero Rodríguez Z, Hernández A, Bracho A, Salazar S, Villalobos R (2013) Prevalencia de microsporidios intestinales y otros enteroparásitos en pacientes con VIH positivo de Maracaibo, Venezuela. Biomédica Revista del Instituto Nacional de Salud 33(4): 1468.

21. Rosa MC, Lobato RC, Gonçalves CV, Silva NMO, Barral MFM (2015) Evaluation of factors associated with vertical HIV-1 transmission. Journal Pediatria (Rio J) 91(6): 523-528.

22. Aguiar JIA, Gonçalves AQ, Sodré FC, Pereira SR, Márcio Neves Bóia MN (2007) Intestinal protozoa and helminths among Terena Indians in the State of Mato Grosso do Sul: high prevalence of Blastocystis hominis. R Soc Bras Med Trop 40(6): 631-634.

23. Watanabe K, Aoki T, Nagata N, Tanuma J, Kikuchi Y, et al. (2014) Clinical significance of high anti-Entamoeba histolytica antibody titer in asymptomatic HIV-1-infected individuals. J Infect Dis 209(11): 18011807.

24. Speich B, Marti H, Ame SM, Ali SM, Bogoch II, et al. (2013) Prevalenc of intertinal protozoa infection among school- aged children on Pemba Island, Tanzania, and effect of single- dose albendazole, nitazoxanide and albendazole - nitazoxanide. Parasit Vectors 4(6): 1-8. 
25. Cimerman S, Casteñda CG, Iuliano WA, Palacios R (2001) Profile of intestinal parasites diagnosed in hiv infected patients in the haart era at a reference center in São Paulo, Brazil. Parasit latino-americana 57(3-4): 111-119.

26. Almeida JC, de Paula CMS, Svoboda WK, Lopes MO, Pilonetto MP, et al. (2013) Perfil epidemiológico de casos de surtos de doenças transmitidas por alimentos ocorridos no Paraná, Brasil. Semina: Ciências Biológicas e da Saúde 34(1): 97-106.

27. Abaver DT, Nwobegahay JM, Goon DT, Iweriebor BC, Anye DN (2011) Prevalence of intestinal parasitic infections among HIV/AIDS patients from two health institutions in Abuja, Nigeria. Afr Health Sci 1: S24-27.

28. Alemu A, Shiferaw Y, Getnet G, Yalew A, Addis Z (2011) Opportunistic and other intestinal parasites among HIV/AIDS patients attending Gambi higher clinic in Bahir Dar city, North West Ethiopia. Asian Pac J Trop Med 4(8): 661-665.

29. Mamo H, Aroian RV (2014). Intestinal Parasitic Infections among Prison Inmates and Tobacco Farm Workers in Shewa Robit, North-Central Ethiopia. Plos one 9(6): 12-18.

30. Petithory JC, Derouin F (1987) AIDS and strongiloidiasis in Africa (letter). Lancet 1(8538): 921.

31. Getaz L, Da Silva-Santos L, Wolff H, Vitoria M, Serre-Delcor N (2016) Persistent infectious and tropical diseases in immigrant correctional populations. Rev Esp Sanid Penit 18(2): 57-66.

32. Bar Yoseph H, Zohar Y, Lorber M (2017) Strongyloidiasis-Related IRIS. J Int Assoc Provid AIDS Care 16(1): 8-10.

33. Bollela VR, Feliciano C, Teixeira AC, Junqueira ACR, Ross MA, et al. (2013) Fulminant gastrointestinal hemorrhage due to Strongyloides stercoralis hyperinfection in an AIDS patient. Rev Soc Bras Med Trop 46(1): 111113.

\section{ISSN: 2574-1241}

DOI: 10.26717/BJSTR.2019.15.002631

Eleuza Rodrigues Machado. Biomed J Sci \& Tech Res

This work is licensed under Creative

Commons Attribution 4.0 License

Submission Link: https://biomedres.us/submit-manuscript.php
34. Ursini T, Polilli E, Fazii P, Ieraci A, Sindic G (2013) Late diagnosis of central nervous system involvement associated with lethal dissemination of Strongyloides stercoralis in an advanced HIV patient from Nigeria. Int J Infect Dis 17(4): 280-282.

35. Figueiró Filho EA, Lopes AHA, Senefonte FRA, Souza Júnior VG, Botelho CA (2005) Toxoplasmose aguda: estudo da freqüência, taxa de transmissão vertical e relação entre os testes diagnósticos maternofetais em gestantes em estado da Região Centro-Oeste do Brasil. Rev Bras Ginecol Obstet 27(8): 442-449.

36. Reiche EMV, Morimoto HK, Farias GN, Hisatsugu KR, Geller L, et al. (2000) Prevalência de tripanossomíase americana, sífilis, toxoplasmose rubéola, hepatite B, hepatite Ce da infecção pelovírus da imunodeficiência humana, avaliada por intermédio de testes sorológicos, em gestantes atendidas no período de 1996 a 1998 no Hospital Universitário Regional Norte do Paraná (Universidade Estadual de Londrina, Paraná, Brasil). Rev Soc bras Med trop 33(6): 519-527.

37. Nunes FVA, Vaez JR, Pinheiro RR, Cavalcante ACR, Ricardo WA, et al. (2013) Seroprevalence and factors associated with Toxoplasma gondii infection in goats on farms in the municipality of Mossoró, Rio Grande do Norte, Brazil. Pesquisa Veterinária Brasileira 33(5): 565-570.

38. Galhardo MCG, Martins IA, Hasslocher Moreno A, Xavier SS, Janice Coelho JMC, et al. (1999) Reativação da infecção por Trypanosoma cruzi em paciente com síndrome de imunodeficiência adquirida. Rev Soc Bras Med Trop 32(3): 291-294.

39. Salvador F, Molina I, Sulleiro E, Burgos J, Curran A, et al. (2013) Tropical diseases screening in immigrant patients with human immunodeficiency virus infection in Spain. Am J Trop Med Hyg 88(6): 1196-1202.

40. Hernández C, Cucunubá Z, Parra E, Toro G, Zambrano P, et al. (2014) Chagas disease (Trypanosoma cruzi) and HIV co-infection in Colombia. International Journal of Infectious Diseases 26: 146-148.

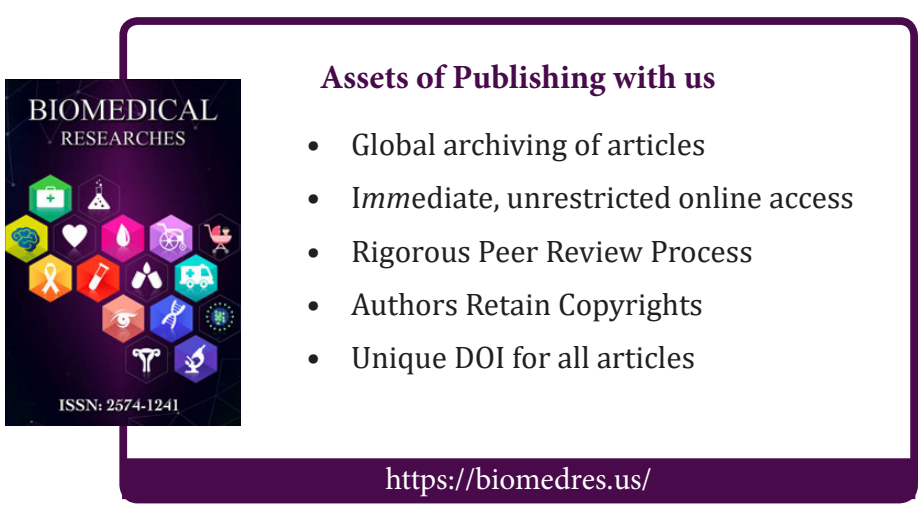

